\title{
O PAPEL DO AUTOR NOS ESTUDOS DO DIREITO NA OU ATRAVÉS DA LITERATURA ${ }^{1}$
}

\author{
THE AUTHOR'S ROLE IN THE LAW IN OR THROUGH LITERATURE \\ EL PAPEL DEL AUTOR EN LOS ESTUDIOS DE DERECHO EN O A TRAVÉS DE \\ LA LITERATURA
}

\author{
ANDRÉ KARAM TRINDADE \\ https://orcid.org/0000-0001-5102-3673 / http://lattes.cnpq.br/0020455190187187 / andre@rdl.org.br \\ UniFG - Centro Universitário \\ Guanambi, BA, PR, Brasil
} https://orcid.org/0000-0002-2166-1321 / http://lattes.cnpq.br/2731124187247021 / h.karam@terra.com.br UniFG - Centro Universitário Guanambi, BA, PR, Brasil

GUILHERME GONÇALVES ALCÂNTARA https:// orcid.org/0000-0002-2210-1270 / http://lattes.cnpq.br/3545235149164538 / guilhermealcantara@msn.com UniFG - Centro Universitário Guanambi, BA, PR, Brasil

\begin{abstract}
RESUMO
Este artigo discute o papel do autor, a partir das formulações de teóricos da literatura, adota a hermenêutica filosófica como matriz teórica e tem como objetivo contribuir para o debate teórico-metodológico que envolve as pesquisas e estudos em Direito e Literatura. Para tanto, são oferecidos postulados teóricos que, relativos ao papel do autor, foram desenvolvidos pelas principais correntes da crítica literária moderna, culminando com a ideia da morte do autor e a discussão dela decorrente. A seguir, abordam-se a noção de círculo hermenêutico e sua relação com o percurso analítico-interpretativo que articula autor, texto e leitor na interpretação de narrativas literárias. Por fim, busca-se demonstrar - através do romance "1984", de George Orwell - em que medida o contexto histórico do autor pode colaborar para a atribuição de sentido ao texto.
\end{abstract}

Palavras-chave: autor; direito; hermenêutica; leitor; literatura; texto.

\begin{abstract}
This article discusses the role of the author, by the formulations of theorists of literature, adopts philosophical hermeneutics as a theoretical matrix and aims to contribute to the theoretical-methodological debate that involves research and studies in law and literature. To this purposes, theoretical postulates are offered in which, concerning the author's role, were developed by the main currents of modern literary criticism, culminating with the idea of the author's death and the resulting discussion. Next, we approach the notion of the hermeneutic circle and its relationship with the analytic-interpretative path that articulates author, text and reader in the interpretation of literary narratives. Finally, we seek to demonstrate - through George Orwell's novel "1984" - the extent to which the author's historical context can contribute to the attribution of meaning to the text.
\end{abstract}

Keywords: author; hermeneutics; law; literature; reader; text.

1 Este artigo é resultado parcial de pesquisas desenvolvidas junto ao Programa de Pós-Graduação em Direito da UniFG, no âmbito do SerTão - Núcleo Baiano de Direito e Literatura (DGP/CNPq). 


\section{RESUMEN}

Este artículo discute el papel del autor, en base a las formulaciones de los teóricos de la literatura, adopta la hermenéutica filosófica como matriz teórica y tiene como objetivo contribuir al debate teórico-metodológico que implica la investigación y los estudios en Derecho y Literatura. Con este fin, ofrece los postulados teóricos que, con respecto al papel del autor, fueron desarrollados por las principales corrientes de la crítica literaria moderna, que culminaron con la idea de la muerte del autor y la discusión de ella resultante. A continuación, aborda la noción de círculo hermenéutico y su relación con el camino analítico-interpretativo que articula autor, texto y lector en la interpretación de narraciones literarias. Finalmente, busca demostrar, a través de la novela "1984", de George Orwell, hasta qué punto el contexto histórico del autor puede contribuir a la atribución de significado al texto.

Palabras clave: autor; derecho; hermenéutica; lector; literatura; texto.

\section{SUMÁRIO}

CONSIDERAÇÕES INICIAIS - O DÉFICIT TEÓRICO E METODOLÓGICO NOS ESTUDOS E PESQUISAS EM DIREITO E LITERATURA; 1 A MORTE DO AUTOR NA TEORIA LITERÁRIA; 2 AUTOR, TEXTO E LEITOR NO CÍRCULO HERMENÊUTICO; 3 O QUE OS ESTUDOS E PESQUISAS EM DIREITO E LITERATURA TÊM A GANHAR COM O DEBATE - O EXEMPLO DE GEORGE ORWELL; CONCLUSÃO; REFERÊNCIAS.

\section{CONSIDERAÇÕES INICIAIS - O DÉFICIT TEÓRICO E METODOLÓGICO NOS ESTUDOS E PESQUISAS EM DIREITO E LITERATURA}

Afirmar que a comunidade jurídica tem muito a ganhar com os estudos e pesquisas em Direito e Literatura requer que sejam apresentados, ao menos para os céticos, quais seriam esses ganhos. Entre as oportunidades proporcionadas pela intersecção entre Direito e Literatura, incluem-se: I) reconhecer que o direito é uma ficção e, assim, insolitamente, aproximá-lo da realidade humana, existencializando-o²; II) colocar em paralaxe ${ }^{3}$ o jurista que se encontra

\footnotetext{
2 A esse respeito, André Karam Trindade afirma: “[...] a literatura atua na direção oposta à do entorpecimento da emoção que leva à prática de atos desumanos e à impossibilidade de comunicação com o outro. Assim, se a obra literária mostra-se capaz de incitar, no plano da fantasia, o sentimento de empatia do leitor em relação aos acontecimentos narrativos e às personagens das histórias contadas - 0 que the possibilita participar, de maneira segura, da vida dos outros, experimentar outras situações -; no plano da realidade, ela conduz a refletir e a se posicionar criticamente a respeito de questões fundamentais do mundo prático" (TRINDADE, André Karam. Direito, literatura, emancipação: um ensaio sobre o poder das narrativas. Revista Jurídica, v. 3, n. 44, p. 86-116, 2016. p. 111). Ver, também, GAAKEER, Jeanne. Por que o direito precisa das ciências humanas: julgando pela experiência. Anamorphosis - Revista Internacional de Direito e Literatura, v. 5, n. 1, p. 5-14, jan.-jun. 2019; STRECK, Lenio Luiz; KARAM, Henriete. A literatura ajuda a existencializar o direito. Anamorphosis - Revista Internacional de Direito e Literatura, v. 4, n. 2, p. 615-626, jul.-dez. 2018; e ESPÍNDOLA, Angela Araújo da Silveira. Entre a insustentabilidade e a futilidade: a jurisdição, o direito e o imaginário social sobre o juiz. Anamorphosis - Revista Internacional de Direito e Literatura, v. 2, n. 2, p. 293-320, jul.-dez. 2016.

3 "A definição padrão de paralaxe é: o deslocamento aparente de um objeto (mudança de sua posição em relação ao fundo) causado pela mudança do ponto de observação que permite nova linha de visão. É claro que o viés filosófico a ser acrescentado é que a diferença observada não é simplesmente 'subjetiva', em razão do fato de que o mesmo objeto que existe 'lá fora' é visto a partir de duas posturas ou pontos diferentes. Mais do que isso, como diria Hegel, sujeito e objeto são inerentemente 'mediados', de modo
} 
ISSN 1981-3694

(DOI): 10.5902/1981369440148

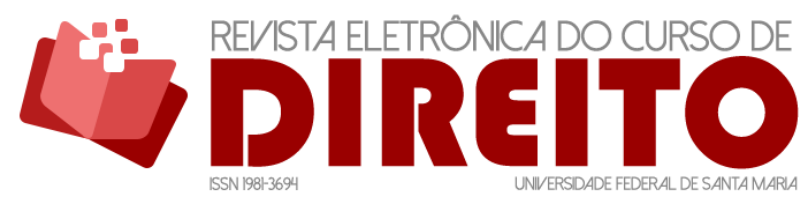

O PAPEL DO AUTOR NOS ESTUDOS DO DIREITO NA OU ATRAVÉS

DA LITERATURA

ANDRÉ KARAM TRINDADE HENRIETE KARAM

GUILHERME GONÇALVES ALCÂNTARA

imerso no senso comum teórico, a fim de aprofundar, problematizar e qualificar seus julgamentos políticos e morais ${ }^{4}$; III) oferecer uma alternativa à crescente tendência neoliberal que invade o ensino jurídico, bem como sua pretensão de colocar o direito a reboque da economia ${ }^{5}$; IV) consolidar uma cultura dos direitos humanos, algo essencial em países cujo histórico é de débito democrático e constitucional, como é o caso do Brasil ${ }^{6}$.

Embora emergente, esse campo de estudo interdisciplinar não constitui, propriamente, novidade, nem no cenário internacional, tampouco no Brasil. Os precursores do movimento, brasileiros e estrangeiros, despontam no cenário do início do século passado, e, desde então, os estudos e pesquisas envolvendo Direito e Literatura têm aumentado de forma exponencial. Vide, no quadro nacional, a já decenária transmissão do programa de TV Direito \& Literatura ${ }^{7}$, a fundação da Rede Brasileira Direito e Literatura (RDL), a criação da Revista Anamorphosis, além dos eventos, projetos de pesquisa, grupos de estudos e produções bibliográficas dedicados à área.

Com base na tipologia de François Ost $^{8}$, pode-se afirmar que existem cinco tipos de abordagem do Direito e Literatura, que amiúde se comunicam: I) Direito da Literatura, que trata principalmente da liberdade de expressão literária e dos direitos autorais; II) Direito na Literatura, campo em que se propõe a análise-interpretativa de problemas político-jurídicos em textos (iterários; III) Direito como Literatura, a análise do discurso jurídico através dos conceitos da teoria literária9; IV) Literatura no Direito, isto é, o uso de obras literárias como argumento jurídico; e, finalmente, V) Literatura como Direito, o estudo de obras literárias manifestamente

que uma mudança 'epistemológica' do ponto de vista do sujeito sempre reflete a mudança 'ontológica' do próprio objeto" (ZIZEK, Slavoj. A visão em paralaxe. Trad. de Maria Beatriz de Medina. São Paulo: Boitempo, 2008. p. 32).

${ }^{4}$ Sugere-se a leitura de PÊPE, Albano Marcos Bastos. Direito e literatura: uma intersecção possível? Interlocuções com o pensamento waratiano. Anamorphosis - Revista Internacional de Direito e Literatura, v. 2, n. 1, p. 5-15, jan.-jun. 2016; e SEATON, James. Law and Literature: Works, Criticism, and Theory. Yale Journal of Law \& the Humanities, v. 11, iss. 2, Article 8, p. 479-507, 1999. p. 507.

${ }^{5}$ Ver: WEST, Robin. Economic Man and Literary Woman: One Contrast. Georgetown Public Law and Legal Theory Research, Paper n. 11-52. Georgetown University Law Center, 1988.

${ }^{6}$ CANDIDO, Antonio. Vários escritos. 5. ed. Rio de Janeiro: Ouro sobre Azul, 2013. p. 174-178.

${ }^{7}$ O programa de tv Direito \& Literatura é produzido pela RDL, em parceria com a TV Unisinos, e vai ao ar, semanalmente, pela TV Justiça.

8 OST, François. Direito e literatura: os dois lados do espelho. Anamorphosis - Revista Internacional de Direito e Literatura, v. 3, n. 1, p. 259-274, jan.-jun. 2017. p. 262.

${ }^{9}$ Isso fica muito claro quando se percebe que o processo judicial é um conjunto de narrativas: do autor, do réu, das testemunhas, do perito, dos serventuários, da polícia, do juiz, dos desembargadores, dos ministros etc. Como diz Ost, "é de uma face a outra que a jurisdictio é penetrada pela narrativa, que é reconstrução imaginária de seu contexto e produção narrativa de seu sentido" (OST, op. cit., p. 261). De igual modo, evidencia-se nas formulações de Dworkin, quando ele oferece o modelo da chain novel para ilustrar a decisão judicial no common law norte-americano (DWORKIN, Ronald. 0 império do direito. Trad. de Jefferson Luiz Camargo. São Paulo: Martins Fontes, 2003). 
ISSN 1981-3694

(DOI): 10.5902/1981369440148

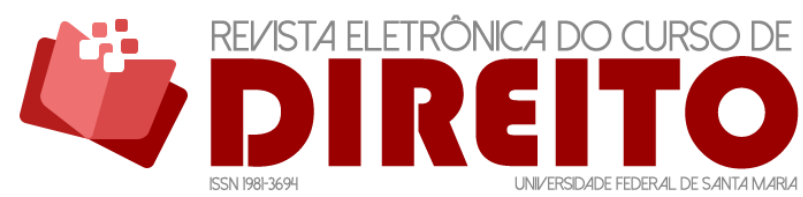

O PAPEL DO AUTOR NOS ESTUDOS DO DIREITO NA OU ATRAVÉS

DA LITERATURA

ANDRÉ KARAM TRINDADE HENRIETE KARAM

GUILHERME GONÇALVES ALCÂNTARA

dedicadas a influenciar o universo jurídico - como exemplo, tem-se J'accuse de Émile Zola, Marginália, de Lima Barreto e Operação massacre de Rodolfo Walsh.

Apesar dos inúmeros benefícios e da evidente expansão do estudo e pesquisa interdisciplinar em Direito e Literatura, a produção bibliográfica nessa área apresenta sérios problemas teóricos e metodológicos. Os pesquisadores, ao menos no cenário nacional, não têm conferido atenção suficiente ao aparato necessário para converter dóxa (סóła) em epistéme

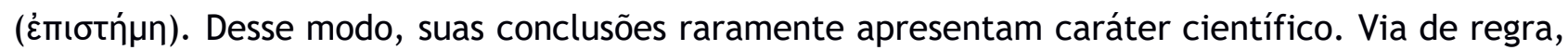
permanecem no senso comum, ou no senso comum teórico. A literatura, para esses pesquisadores, tem valor decorativo, é mero ornamento argumentativo ${ }^{10}$. Isso contribui, ao fim, com o descrédito e trivialidade desses estudos.

A maioria das pesquisas nesse campo é feita por juristas ou estudantes de Direito que empregam a literatura de forma ornamental ${ }^{11}$ : o texto literário desempenha o papel de adorno, que confere charme à (hipó)tese do pesquisador. Em termos hermenêuticos, simplesmente se interpreta do texto aquilo que já se atribuiu a ele de antemão. Reproduzem-se pré-concepções de mundo. Esse problema aparece principalmente no campo de estudo do Direito na ou através da Literatura $^{12}$. Utiliza-se a obra literária para legitimar uma opinião não submetida à experiência, ou seja, um pré-juízo, a respeito de questões político-jurídicas. Entretanto, mesmo que - seguindo o conselho de Heidegger - se aceite que os pré-juízos são condição da possibilidade de compreender, eles sempre podem (e devem) ser colocados em suspensão quando no diálogo com o texto. Só assim se pode ouvir o ser da obra de arte, que diz: deves mudar tua vida ${ }^{13}$. A literatura, como se verá, ocupa uma posição-limite para a hermenêutica

${ }^{10}$ TRINDADE, André Karam; BERNSTS, Luísa Giuliani. O estudo do Direito e literatura no Brasil: surgimento, evolução e expansão. Anamorphosis - Revista Internacional de Direito e Literatura, Porto Alegre, RDL, v. 3, n. 1, p. 225-257, jan.-jun. 2017. p. 246-247.

11 Consulte: KARAM, Henriete. O direito na contramão da literatura: a criação no paradigma contemporâneo. Revista Eletrônica do Curso de Direito da UFSM, v. 12, n. 3, p. 1022-1043, dez. 2017 a. p. 1023; e KARAM, Henriete. Questões teóricas e metodológicas do direito na literatura: um percurso analítico-interpretativo a partir do conto "Suje-se gordo!", de Machado de Assis. Rev. direito GV, v. 13, n. 3, p. 827-865, dez. 2017b. p. 828.

12 Importa destacar que esse é um problema que parece existir também nos estudos norte-americanos. Robert Weisberg, a título de exemplo, identifica que muitos estudos e pesquisas do direito na literatura em seu país produzem resultados intelectualmente acanhados, porque combinam leituras convencionais dos textos literários com leituras complacentes de questões jurídicas, às vezes mascarando-se nos tons auto-congratulatórios da compreensão cultural (WEISBERG, Robert. The Law-Literature Enterprise. Yale Journal of Law \& the Humanities, v. 1, iss. 1, Article 4, p. 1-68, 1989. p. 2-3).

13 GADAMER, Hans-Georg. Estética y Hermenéutica. Trad. de José Francisco Zúñiga García. Daimon Revista Internacional de Filosofía, n. 12, p. 1-8, 1996. p. 8. 
ISSN 1981-3694

(DOI): 10.5902/1981369440148

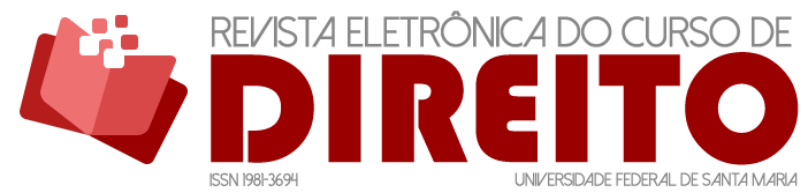

O PAPEL DO AUTOR NOS ESTUDOS DO DIREITO NA OU ATRAVÉS

DA LITERATURA

ANDRÉ KARAM TRINDADE HENRIETE KARAM

GUILHERME GONÇALVES ALCÂNTARA

filosófica, na medida em que o ler constitui temporalmente os sentidos, "toda forma de leitura compreensiva é sempre também uma forma de re-produção e interpretação"14.

O papel ou função do autor na interpretação do texto literário é das mais problemáticas no âmbito da teoria e da crítica literária contemporânea. Assim, a sua elucidação para o estudo em Direito e Literatura é fundamental, na medida em que interfere diretamente no lugar do sentido do texto literário - e, para alguns autores como Gadamer e Foucault, de todos os textos. Toda pesquisa nesse campo interdisciplinar, portanto, precisa tomar uma posição teórica a respeito da questão do autor, sob pena de incorrer na mera instrumentalização do texto literário.

Este artigo discute o papel do autor, a partir das formulações de teóricos da literatura, e tem como objetivo contribuir para o debate teórico-metodológico que envolve as pesquisas e estudos em Direito e Literatura. A primeira parte é dedicada a traçar um breve panorama histórico da teoria literária moderna, enfocando a relevância ou não do autor nos constructos teóricos de diferentes correntes da crítica literária, ao longo dos séculos XIX e XX.. Em seguida, com base na hermenêutica filosófica, é abordada a noção de círculo hermenêutico, a fim de relacioná-la com o percurso analítico-interpretativo que, proposto por $\mathrm{H}$. Karam ${ }^{15}$, possibilita articular autor, texto e leitor, na pesquisa em Direito e Literatura. Ao final, busca-se demonstrar - através do romance 1984, de George Orwell - em que medida o contexto histórico do autor pode colaborar para a atribuição de sentido ao texto.

\section{A MORTE DO AUTOR NA TEORIA LITERÁRIA}

Identificam-se, segundo o relato sumário de Terry Eagleton ${ }^{16}$, três fases da teoria literária moderna: I) o romantismo do século XIX; II) o estruturalismo francês e o new criticism norteamericano; III) e a teoria da recepção. Conforme destaca Henriete Karam:

Será somente no final do séc. XVIII, com a eclosão do movimento alemão denominado Sturm und Drung (tempestade e ímpeto), decorrente da oposição aos princípios preconizados pelo iluminismo francês e que dá origem ao Romantismo, que surgem os postulados estéticos que - a partir da noção de gênio, entendido como espírito criativo - irão dar destaque à ideia de que 'a arte

\footnotetext{
${ }^{14}$ GADAMER, Hans-Georg. Verdade e método, vol. I: traços fundamentais de uma hermenêutica filosófica. Trad. de Flávio Paulo Meurer. Petrópolis: Vozes, 1997. p. 257.

15 KARAM, 2017b.

${ }^{16}$ EAGLETON, Terry. Teoria da literatura: uma introdução. Trad. de Waltemir Dutra. 6. ed. São Paulo: Martins Fontes, 2006. p. 113.
} 
ISSN 1981-3694

(DOI): 10.5902/1981369440148

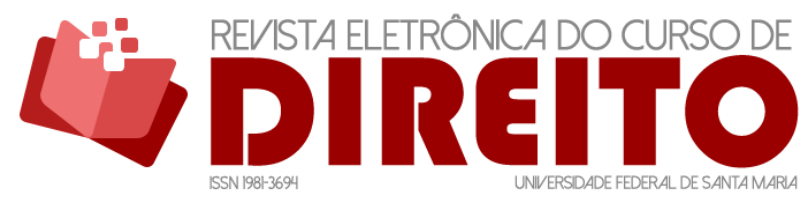

O PAPEL DO AUTOR NOS ESTUDOS DO DIREITO NA OU ATRAVÉS

DA LITERATURA

ANDRÉ KARAM TRINDADE HENRIETE KARAM

GUILHERME GONÇALVES ALCÂNTARA

é arte como expressão de uma subjetividade incalculável e não mensurável por normas'"17.

A teoria literária moderna inicia no século XIX, impulsionada por essa concepção de espírito criativo, que supervaloriza o autor, e pelo surgimento do próprio romance moderno. Se, desde a Antiguidade, o romance levava uma "existência não oficial, fora do limiar da grande literatura" ${ }^{18}$, a partir da segunda metade do séc. XVIII, ele se torna, paulatinamente, o gênero predominante, justamente porque, como destaca Mikhail Bakhtin, “o romance não é simplesmente mais um gênero ao lado dos outros [...] ele é o único nascido e alimentado pela era moderna na história mundial e, por isso, profundamente aparentado a ela"19. De tal forma que o romance constitui o paradigma da literatura moderna, sempre se reinventando de inúmeras formas (realismo, naturalismo, impressionismo, realismo fantástico etc.).

Particularmente interessante, no que diz respeito ao escopo deste artigo, é o fato de que o fenômeno do isolamento do autor, que ao escrever um romance procura levar o incomensurável de sua própria vida aos últimos limites ${ }^{20}$, conduz a hermenêutica literária do século XIX à psicologia do autor. Para tanto, foram decisivas as influências de Scheleiermacher ${ }^{21}$ e de Dilthey. Foi principalmente em virtude da hermenêutica desenvolvida pelo primeiro que a teoria literária empenhou-se na tentativa de desvendar a intenção autoral por detrás do texto ${ }^{22}$, identificando e vinculando o sentido da obra com a intenção do autor ${ }^{23}$.

17 KARAM, 2017a, p. 1025; KORFMANN, Michael. A diferenciação da literatura moderna alemã no processo constitutivo da sociedade funcional: uma abordagem sistêmica baseada em Niklas Luhman. 2002. $274 \mathrm{f}$. Tese (Doutorado em Letras)- Instituto de Letras, Universidade Federal do Rio Grande do Sul, Porto Alegre, 2008. p. 126.

${ }^{18}$ BAKHTIN, Mikhail. Questões de literatura e de estética: a teoria do romance. Trad. de Aurora Fornoni Bernardini et al. São Paulo: Unesp; Hucitec, 1988. p. 398.

19 lbidem, p. 398.

20 BENJAMIN, Walter. Obras escolhidas, I; Magia e técnica, arte e política: ensaios sobre literatura e história da cultura. Trad. de Sérgio Paulo Rouanet. 3. ed, São Paulo: Brasiliense. 1987. p. 201.

21 "Como todo discurso tem uma dupla relação, com a totalidade da linguagem e com o pensar geral de seu autor: assim também toda compreensão consiste em dois momentos; compreender o discurso enquanto extraído da linguagem e compreendê-lo enquanto fato naquele que pensa" (SCHELEIERMACHER, Friedrich D. Hermenêutica e crítica: com anexos de Scheleiermacher sobre filosofia da linguagem, vol. I. Trad. de Aloísio Ruedell. Ijuí: Ed. Ijuí, 2005. p. 95.

22 "Se o acesso ao mundo [depois de Kant], e em nosso caso ao texto, ocorre sempre através de uma interpretação ou de um parecer subjetivo, então a reflexão filosófica que pretende ser originária, deve iniciar por este sujeito. Em sua esfera deve, por exemplo, ser levantada a questão, como pode e se realmente pode ser obtida a objetividade em assuntos científicos ou hermenêuticos" (GRONDIN, Jean. Introdução à hermenêutica filosófica. Trad. de Benno Dischinger. São Leopoldo: Ed. UNISINOS, 1999. p. 119.

${ }^{23}$ COMPAGNON, Antoine. 0 demônio da teoria: literatura e senso comum. Trad. de Cleonice Paes Barreto Mourão. Belo Horizonte: Ed. UFMG, 1999. p. 47. 
ISSN 1981-3694

(DOI): 10.5902/1981369440148

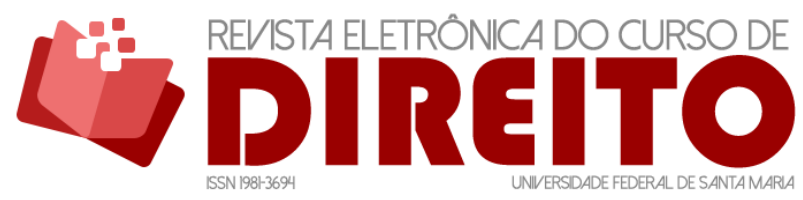

O PAPEL DO AUTOR NOS ESTUDOS DO DIREITO NA OU ATRAVÉS

DA LITERATURA

ANDRÉ KARAM TRINDADE HENRIETE KARAM

GUILHERME GONÇALVES ALCÂNTARA

No século XIX, portanto, a teoria literária permanecia caudatária da hermenêutica, principalmente a partir da universalização de Scheleiermacher. Esse panorama muda profundamente no século XX, a começar pelos estudos desenvolvidos pelos formalistas russos ${ }^{24}$, que influenciaram diretamente o estruturalismo ${ }^{25}$.

A pesquisa literária adquire com os formalistas russos sua autonomia: desprezando questões atinentes à produção literária e opondo-se às tendências psicologizantes e sociologizantes, seu interesse concentra-se no discurso literário e no funcionamento do sistema literário. Analisar seus elementos constitutivos, evidenciar suas leis, em suma, interpretar a significação da obra literária a partir de seu próprio código ${ }^{26}$. A psicologia do autor começa a dar seus sinais de esgotamento a partir dos formalistas russos ${ }^{27}$, os quais passaram a considerar "a obra mesma, o texto literário, como um sistema imanente"28, o que se estende para os estruturalistas, interessados no funcionamento do discurso literário e nos elementos constitutivos e estruturais do texto literário ${ }^{29}$. Também o new criticism norte-americano ${ }^{30}$, do outro lado do Atlântico, denunciava a falácia intencional como prejudicial à análise literária ${ }^{31}$.

${ }^{24} \mathrm{O}$ formalismo russo surgiu em 1914, quando um grupo de alunos da Universidade de Moscou fundou o Círculo Linguístico de Moscou, com o objetivo de desenvolver pesquisas nos campos da linguística e da poética; em 1917, é reforçado pela colaboração dos membros da Sociedade para os Estudos da Linguagem Poética (OPOJAZ), de São Petersburgo; em 1930, o grupo é extinto, por razões políticas.

${ }^{25}$ Ao abordar as relações entre o formalismo e o estruturalismo, Todorov afirma: "O método estrutural, desenvolvido primeiramente na linguística, encontra partidários cada vez mais numerosos em todas as ciências humanas, inclusive no estudo da literatura. Essa evolução parece tanto mais justificada quanto, entre as relações da língua com as diferentes formas de expressão, as que a unem à literatura são profundas e numerosas. Não é, aliás, a primeira vez que se opera essa aproximação. A origem do Círculo Linguístico de Praga, uma das primeiras escolas da linguística estrutural, é justamente o "formalismo russo". A relação entre um e outro é incontestável: estabeleceu-se tanto por intermédio daqueles que participaram dos dois grupos, simultânea ou sucessivamente (R. Jakobson, B. Tomachévski, P. Bogatirióv), quanto pelas publicações dos formalistas, que o Círculo de Praga não ignorou" (TODOROV, Tzvetan. As estruturas narrativas. Trad. de Leyla Perrone-Moisés. São Paulo: Perspectiva, 2006. p. 26-27).

${ }^{26}$ Ibidem, p. 30-31.

270 método estrutural, desenvolvido primeiramente na linguística, encontra partidários cada vez mais numerosos em todas as ciências humanas, inclusive no estudo da literatura. Essa evolução parece tanto mais justificada quanto, entre as relações da língua com as diferentes formas de expressão, as que a unem à literatura são profundas e numerosas. Não é, aliás, a primeira vez que se opera essa aproximação. A origem do Círculo Lingüístico Linguístico de Praga, uma das primeiras escolas de linguística estrutural, não é outra senão uma corrente de estudos literários que se desenvolveu na Rússia durante os anos 1915-1930, e que é conhecida sob o nome "formalismo russo". A relação entre um e outro é incontestável: estabeleceu-se tanto por intermédio daqueles que participaram dos dois grupos, simultânea ou sucessivamente (R. Jakobson, B. Tomachévski, P. Bogatirióv), quanto pelas publicações dos formalistas, que o Círculo de Praga não ignorou (TODOROV, op. cit., p. 19).

${ }^{28}$ Ibidem, p. 29.

${ }^{29}$ Segundo Todorov, o estruturalismo "Não se satisfaz com uma pura descrição da obra, nem com sua interpretação em termos psicológicos ou sociológicos [...] Seu objeto é o discurso literário mais do que as obras literárias, a literatura virtual mais do que a literatura real. 0 objetivo desse estudo não é mais articular uma paráfrase, um resumo argumentado da obra concreta, mas propor uma teoria da estrutura e 
ISSN 1981-3694

(DOI): 10.5902/1981369440148

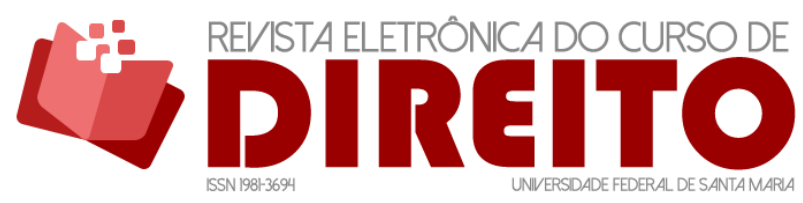

O PAPEL DO AUTOR NOS ESTUDOS DO DIREITO NA OU ATRAVÉS

DA LITERATURA

ANDRÉ KARAM TRINDADE HENRIETE KARAM

GUILHERME GONÇALVES ALCÂNTARA

O estruturalismo, na linguística, seguiu o mesmo caminho durante o início do século XX, “tanto nos princípios gerais quanto em certas técnicas de análise”32. Assim, a radical oposição à crítica literária de viés psicológico ou sociológico é compartilhada pelos teóricos vinculados ao formalismo, ao new criticismo e ao estruturalismo que, desde as primeiras décadas do séc. XX, desconsideram o autor do texto e, consequentemente, afastam-se de posturas intencionalistas.

Mas é somente no final dos anos 60 que Roland Barthes se aventura em anunciar a morte do autor ${ }^{33}$. Avançando para o pós-estruturalismo, Barthes defende que a escritura ficcional é um composto, um tecido, neutro e oblíquo, "pelo qual foge o nosso sujeito [...] o autor entra na sua própria morte, [quando] a escritura começa" ${ }^{34}$, o que vale apenas para aquilo que é contado simbolicamente, isto é, sem fim de agir diretamente sobre o real, o que para Barthes (e a tradição estruturalista) corresponde à literatura ${ }^{35}$.

Para Barthes, a tarefa hermenêutica ${ }^{36}$ assumida pela teoria literária havia se comportado como teologia, ao considerar o texto tal como "linha de palavras a produzir um sentido único" ${ }^{37}$. Reconhecer que o texto é "um tecido de citações, oriundas dos mil focos da cultura" 38 torna inútil a pretensão de 'decifrar' um texto através da identificação das intenções contidas nele. Reconhecer o texto como esse tecido é uma atitude, pois, contra-teológica ${ }^{39}$. A ideia da morte do autor promovida por Barthes, no campo literário, encontra equivalência com a morte de Deus anunciada por Nietzsche, no campo da filosofia. Desvendar "o ser total da escritura", afirma Barthes, é analisar as "escrituras múltiplas, oriundas de várias culturas e que

do funcionamento do discurso literário, apresentar um quadro dos possíveis literários, do qual as obras literárias existentes aparecem como casos particulares rea1izados (TODOROV, op. cit., p. 79-80).

30 O new criticismo ou nova crítica adquiriu importância, sobretudo nos EUA, entre as décadas de 20 e 30 do séc. XX.

31 COMPAGNON, op. cit., p. 47.

32 TODOROV, op. cit., p. 19.

$33 \mathrm{O}$ artigo de Barthes intitulado "A morte do autor" - publicado, originalmente, em inglês ("The Death of the Author"), na Aspen Magazine, n. 5-6, 1967, e, em francês ("La mort de l'auteur"), na revista Manteia, n. V, 1968, e na coletânea póstuma Os rumores da língua, em 1984 - e a conferência de Foucault "O que é um autor?", proferida no Collège de France (1969) e na University at Buffalo (1970), são basilares para o Pós-estruturalismo.

34 BARTHES, Roland. A morte do autor. In: BARTHES, Roland. 0 rumor da língua. Trad. de Mario Laranjeira. 2. ed. São Paulo: Martins Fontes, 2004. p. 57-58.

${ }^{35}$ Ibid., p. 58.

${ }^{36}$ Voltando-se para a semiótica, Barthes refuta expressamente qualquer tentativa de fazer hermenêutica literária, isto é, qualquer teoria ou metodologia da interpretação literária, justamente porque não há sentido a ser extraído no texto literário. 0 fato de a literatura não fazer referência ao real, ao contrário dos textos jurídicos, históricos etc., a tolhe(ria) de todo interesse hermenêutico. A semiótica, para Barthes, substitui a hermenêutica.

37 BARTHES, op. cit., p. 62.

38 Id., ibid.

39 Ibid., p. 63. 
ISSN 1981-3694

(DOI): 10.5902/1981369440148

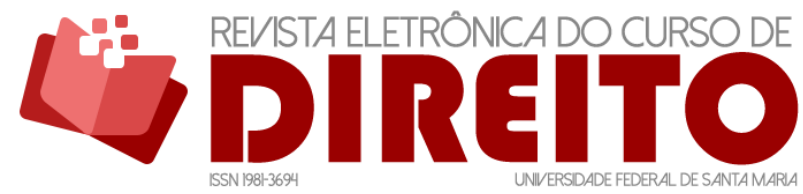

O PAPEL DO AUTOR NOS ESTUDOS DO DIREITO NA OU ATRAVÉS

DA LITERATURA

ANDRÉ KARAM TRINDADE HENRIETE KARAM

GUILHERME GONÇALVES ALCÂNTARA

entram umas com as outras em diálogo, em paródia, em contestação"40. Assim, a inexorável polissemia dos textos literários impediria qualquer conhecimento objetivo da intenção do autor.

Como não poderia deixar de ser, há quem discorde de tais propostas. Harold Bloom, um dos expoentes da crítica literária na atualidade, cunha o termo escola do ressentimento para designar o círculo jornalístico-acadêmico que se opõe à ideia de cânone literário para promover programas de ação social ${ }^{41}$. Para Bloom, a tese da morte do autor é mais um mito anticanônico, similar ao grito de guerra do ressentimento; autores como Shakespeare e Cervantes estão bem vivos, mas noutra ordem de vitalidade. A antiga metáfora da imortalidade dos autores é relevante e renova o poder do cânone até hoje para nós ${ }^{42}$.

De outra forma, E. D. Hirsch Jr. também se insurgira, na década de 60, contra a tese da falácia intencional defendida pelos adeptos do New Criticism e seu entusiasmo com o retorno ao "quê o texto diz", desconsiderando que todo texto tem que representar um significado para alguém - se não o autor, então os leitores, dentre ele, os críticos. Para Hirsch, uma sequência de palavras não significa nada em particular até que alguém queira dizer algo ou entenda algo com aquilo ${ }^{43}$. Alguém faz a conexão entre significados e palavras, e o significado particular que esse alguém empresta às palavras nunca é o único legítimo, de acordo com as convenções linguísticas. Quando os críticos banem o autor da análise literária, na perspectiva de Hirsch, usurpam o seu lugar - onde existia apenas um autor, agora surgem inúmeros ${ }^{44}$. Surgem inúmeras interpretações, e todas elas se pretendem verdadeiras.

Hirsch busca, nesse sentido, a retomada da análise da intenção do autor na teoria literária, com a finalidade de combater esse relativismo. Não aos moldes do romantismo - com a exploração da psicologia do autor - pois, para ele, não podemos, de fato, conhecer a mente do autor enquanto escreve o texto. Hirsch está interessado nos significados compartilhados, aqueles que, consciente ou inconscientemente, são transmitidos pela escrita. A maioria dos autores acredita na acessibilidade aos significados compartilhados nas palavras, caso contrário, sequer escreveriam, postula Hirsch" ${ }^{45}$. No mesmo sentido, Antonio Candido assevera que "além do conhecimento por assim dizer latente, que provém da organização das emoções e da visão do

\footnotetext{
40 Ibid., p. 64.

${ }^{41}$ BLOOM, Harold. O cânone ocidental. Rio de Janeiro: Objetiva, 2010. p. 14-15.

42 Ibid., p. 39.

43 "If a text means what it says, then it means nothing in particular. Its saying has no determinate existence but must be the saying of the author or a reader. The text does not exist even as a sequence of words until it's construed; until then, it's merely a sequence of signs" (HIRSCH JR., E. D. Validity in interpretation. Chelsea, Michigan: BookCrafters, Inc. 1967. p. 13).

44 Ibid., p. 3-5.

45 Ibid., p. 17-18.
} 
ISSN 1981-3694

(DOI): 10.5902/1981369440148

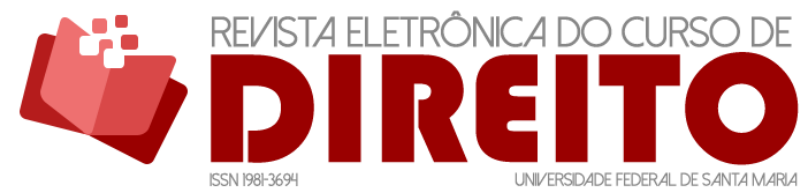

O PAPEL DO AUTOR NOS ESTUDOS DO DIREITO NA OU ATRAVÉS

DA LITERATURA

ANDRÉ KARAM TRINDADE HENRIETE KARAM GUILHERME GONÇALVES ALCÂNTARA

mundo, há, na literatura, níveis de conhecimento intencional, isto é, planejados pelo autor e conscientemente assimilados pelo receptor" ${ }^{\prime 4}$.

Por outro lado, é certo que a teoria literária nunca conseguiu resolver de vez as tensões entre autor e narrador, ou entre narração e discurso. Como afirma Genette, ora o autornarrador interpela deliberadamente o leitor - como ocorre com frequência em romances e contos de Machado de Assis -, ora a responsabilidade da produção discursiva é transferida integralmente para um eu fictício ${ }^{47}$.

Já Foucault defende a existência de uma função-autor que teria relevância para a teoria literária, pois

a função-autor está ligada ao sistema jurídico e institucional que contém, determina, articula o universo dos discursos; ela nasce se exerce uniformemente e da mesma maneira sobre todos os discursos, em todas as épocas e em todas as formas de civilização; ela não é definida pela atribuição espontânea de um discurso ao seu produtor, mas por uma série de operações específicas e complexas; ela não remete pura e simplesmente a um indivíduo real, ela pode dar lugar simultaneamente a vários egos, a várias posições-sujeito que classes diferentes de indivíduos podem vir a ocupar ${ }^{48}$.

Foucault não fala em texto. Ao invés, questiona o que seria obra? o que deve ser publicado com o nome de um autor? Uma carta particular não possui autor no sentido literário. Mas, e se fosse uma carta de Nietzsche? E se essa carta apenas contivesse um aviso de chegada? Para ele, isso (re)coloca os problemas do autor. Assim como Gadamer, Foucault passa suas considerações da literatura para a filosofia, na medida em que fala dos fundadores de discursividade, isto é, aqueles autores - como S. Paulo, Marx, Freud - que ocupam uma posição transdiscursiva: eles instauram teorias, tradições, disciplinas, ou seja, "as regras de formação de outros textos" ${ }^{49}$. De fato, até mesmo Barthes, em O prazer do texto - obra publicada em 1973 -, reconhece a existência de uma função a ser atribuída ao autor:

Como criatura de linguagem, o escritor está sempre envolvido na guerra das ficções (dos falares), mas nunca é mais do que um joguete, porque a linguagem que o constitui (a escritura) está sempre fora de lugar (atópica); pelo simples

\footnotetext{
${ }^{46}$ CANDIDO, op. cit., p. 182. (recusa do presente, da primeira pessoa, etc.)” (Ibid., p. 272).

${ }^{48}$ FOUCAULT, Michel. 0 que é um autor? Lisboa: Veja, 2002. p. 285.

49 Ibid., p. 286-287.
}

47 GENETTE, G. Fronteiras da narrativa. In: BARTHES, R. et al. Análise estrutural da narrativa. Trad. de Maria Zélia Barbosa Pinto. Petrópolis: Vozes, 2011. p. 273. Nesse sentido, “o discurso pode 'narrar' sem cessar de ser discurso, a narrativa não pode 'discorrer' sem sair de si mesma” (Ibid., p. 272). O discurso é a forma universal e "pura" da linguagem, enquanto a narrativa é um modo particular, "definido por um certo número de exclusões e de condições restritivas 
ISSN 1981-3694

(DOI): $10.5902 / 1981369440148$

efeito da polissemia (estádio rudimentar da escritura), o engajamento guerreiro de uma fala literária é duvidoso desde a origem. 0 escritor se encontra sempre sobre a marcha cega dos sistemas, à deriva; é um joker, um mana, um grau zero, o morto do bridge: necessário ao sentido (ao combate), mas ele mesmo privado de sentido fixo; seu lugar, seu valor (de troca) varia segundo os movimentos da história, os golpes táticos da luta: pedem-lhe tudo e/ou nada ${ }^{50}$.

Observa-se, portanto, que a questão do autor continua sendo objeto de muita discussão, no campo da teoria literária. Uma terceira via que se abre, paralelamente aos intencionalistas e aostextualistas, será a do recurso ao leitor, afinal, como declara Barthes: "o nascimento do leitor deve pagar-se com a morte do Autor"51. Assim, o lugar onde os múltiplos sentidos possíveis do texto se unificam não seria a mente do autor, mas a do leitor, pois

o leitor é o espaço mesmo onde se inscrevem, sem que nenhuma se perca, todas as citações de que é feita a escritura; a unidade do texto não está na sua origem, mas no seu destino, mas esse destino já não pode ser pessoal: o leitor é um homem sem história, sem biografia, sem psicologia; ele é apenas esse alguém que mantém reunidos em um mesmo campo todos os traços de que é constituído o escrito ${ }^{52}$

A descoberta da infinita polissemia dos textos colabora para transferir o foco do autor para o leitor, transferência que é consolidada pela base teórica oferecida pela Estética da recepção. Wolfgang Iser, um de seus expoentes, afirma que os autores jogam com os leitores, tendo o texto como campo. O texto é o "resultado de um ato intencional pelo qual um autor se refere e intervém em um mundo existente, mas, conquanto o ato seja intencional, visa a algo que não está acessível à consciência" ${ }^{53}$ e que não pode, portanto, ser passivamente introduzido no leitor. Iser, neste sentido, defende que toda leitura é um processo dinâmico e criativo, e que o leitor sempre (re)interpreta o texto. Nessa alegoria entre processo de interpretação do texto e jogo, algo endossado tanto por Iser quanto por Gadamer, é necessário levar em consideração todos os jogadores, todos os signatários desse "contrato entre autor e leitor ${ }^{54}$, indicador de que o mundo textual há de ser concebido, não como realidade, mas como se fosse realidade" 55 .

${ }^{50}$ BARTHES, Roland. 0 prazer do texto. Trad. de J. Guinsburg. 3. ed. São Paulo: Perspectiva, 2002. p. 4344.

51 BARTHES, 2004, p. 64.

52 Id., ibid.

${ }^{53}$ ISER, Wolfgang. 0 jogo do texto. In: LIMA, Luiz Costa (org.). A literatura e o leitor: textos de estética da recepção. São Paulo: Paz e Terra, 2002. p. 107.

${ }^{54}$ Seria interessante, para os efeitos das pesquisas em Direito e Literatura, diferenciar o leitor literário do leitor jurídico, este último, segundo Túlio Jales, não é somente afetado pela obra e a reinterpreta, como necessita "ir além e convencer terceiros a embarcarem em sua interpretação da obra jurídica. Para além de ser transformado pelo texto, [...] o leitor jurídico precisa ser um transformador dos textos que lê. 


\section{AUTOR, TEXTO E LEITOR NO CÍRCULO HERMENÊUTICO}

A hermenêutica filosófica que desenvolve Hans-Georg Gadamer tampouco deixa de conceber a literatura vinculada ao ato da leitura. A leitura, à primeira vista a operação de reprodução do texto, representa "o modo de ser original de todas as artes transitórias e que se tornou exemplar para a determinação do modo de ser da arte em geral" ${ }^{56}$. O conceito de literatura, pois,

não deixa de estar vinculado ao seu receptor. A existência da literatura não é a sobrevivência morta de um ser alienado, que se desse simultaneamente à realidade vivencial de uma época posterior. A literatura é, antes, uma função da preservação e da transmissão espiritual e traz, por isso, a cada situação presente, a história que nele se oculta ${ }^{57}$.

A diferença de Gadamer para com Barthes é que este restringe sua tese aos textos literários - textos que ele define como fictícios, ou seja, que não tem função de agir diretamente na realidade, como já destacado - e, assim, rejeita qualquer pretensão hermenêutica na literatura. Gadamer, por sua vez, concebe a literatura como todo e qualquer texto. A literatura ocupa posição-limite para a hermenêutica filosófica, na medida em que o ler constitui temporalmente os sentidos, "toda forma de leitura compreensiva é sempre também uma forma de re-produção e interpretação"58. O que se demonstra no início de Verdade $e$ método, a respeito da ontologia da obra de arte, é nada menos que um projeto para a própria hermenêutica filosófica desenvolvida a partir daí. Para Gadamer,

qualquer obra de arte, não apenas as literárias, tem que ser compreendida no mesmo sentido em que se tem de compreender qualquer outro texto, e esse compreender requer gabarito para tal. Com isso a consciência hermenêutica adquire uma extensão tão abrangente, que ultrapassa a da consciência estética.

Nessa dimensão ontológica, o leitor jurídico parece estar fadado a ser sintetizado no personagem mal leitor, aquele que discorda da hermenêutica, que se apresenta como dissidente interpretativo. [...] essa tarefa transformativa deve ser assessorada por uma estética não ocultadora das verdades dos textos" (JALES, Túlio de Medeiros. Quem é o leitor de textos jurídicos? Uma exploração sobre os ombros de Ricardo Piglia. Anamorphosis - Revista Internacional de Direito e Literatura, v. 3, n. 1, p. 25-37, jan.-jun. 2017. p. 35-36).

55 ISER, op. cit., p. 105.

56 GADAMER, 1997, p. 258.

57 Id., ibid., p. 258.

58 Id., ibid., p. 257. 
ISSN 1981-3694

(DOI): 10.5902/1981369440148

A estética deve subordinar-se à hermenêutica. $E$ este enunciado não se refere meramente à periferia do problema, mas vale antes de tudo para o conteúdo. E, inversamente, a hermenêutica tem de determinar-se, em seu conjunto, de maneira que faça justiça à experiência da arte. A compreensão deve ser entendida como parte da ocorrência de sentido, em que se formula e se realiza o sentido de todo enunciado, tanto dos da arte como dos de qualquer outro gênero de tradição ${ }^{59}$.

Gadamer, portanto, universaliza a tese de Barthes sobre a morte do autor - ela vale não apenas para os textos ficcionais, mas para todos os textos. Paradoxalmente, essa universalização se dá com o nítido interesse de reabilitar a hermenêutica literária, refutada por Barthes. Como interpretar o texto, se o autor está morto?

A hermenêutica filosófica, para responder a essa aparente aporia, recorre ao conceito de círculo hermenêutico, a "regra [...] segundo a qual devemos compreender o todo a partir do singular e o singular a partir do todo" ${ }^{60}$, regra que, nascida na retórica antiga e trabalhada na hermenêutica moderna, inicialmente por Scheleiermacher ${ }^{61}$, como método para evitar a mácompreensão dos textos, funcionaria em dois níveis: objetivo, referente à estrutura do texto; e subjetivo, referente à estrutura espiritual do autor. Completado o circuito hermenêutico, para Scheleiermacher, a hermenêutica estaria a salvo de mal-entendidos ${ }^{62}$.

Para Gadamer, entretanto, Scheleiermacher compreende mal a noção do círculo hermenêutico. Nenhum dos dois níveis - nem o objetivo, nem o subjetivo - corresponde propriamente à experiência hermenêutica. O círculo hermenêutico de Scheleiermacher padece de um "achatamento metodológico". Heidegger anteviu isso, quando ressaltou o sentido ontológico-positivo do círculo hermenêutico: não mais um recurso a ser empregado quando a compreensão do texto é obstada, mas condição de possibilidade do entendimento ${ }^{63}$. Heidegger (re)descobre o círculo hermenêutico, na medida em que ressalta o conjunto de pré-concepções que possibilitam e determinam a compreensão, imbricando, consciência hermenêutica e consciência histórica. Exige-se, pois, a partir de Heidegger, a tomada de consciência das concepções prévias de modo a não simplesmente confirmá-las na compreensão do texto ${ }^{64}$.

Gadamer dá um passo adiante a Scheleiermacher e Heidegger: o círculo hermenêutico, para ele, "precisa ser completado por uma outra determinação, que chamo de concepção prévia

59 Id., ibid., p. 263.

60 GADAMER, Hans-Georg. Verdade e método, vol. II: complementos e índices. Trad. de Ênio Paulo Giachini. Petrópolis: Vozes. 2002. p. 72.

61 SCHELEIERMACHER, op. cit.

62 GADAMER,2002, p. 72-74.

${ }^{63}$ Id., ibid., p. 74.

${ }^{64}$ Id., ibid., p. 74-76. 
ISSN 1981-3694

(DOI): $10.5902 / 1981369440148$

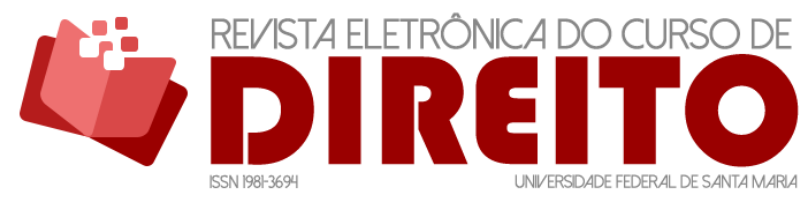

O PAPEL DO AUTOR NOS ESTUDOS DO DIREITO NA OU ATRAVÉS

DA LITERATURA

ANDRÉ KARAM TRINDADE HENRIETE KARAM

GUILHERME GONÇALVES ALCÂNTARA

da perfeição"65. Reconhecer a circularidade hermenêutica é tomar ciência, pois, que vamos ao encontro do texto (pré)concebendo que ele "apresenta uma unidade de sentido completa" ${ }^{66}$. Não se trata da mesma noção de "código" ou "sistema" que guia o estruturalismo, porque a concepção prévia da completude de que fala Gadamer não é meramente formal, ela se refere também ao conteúdo - ou significado - do texto: “o entendimento do leitor está sendo constantemente guiado por expectativas de sentido transcendentes, que brotam da relação com a verdade do que se tem em mente" ${ }^{67}$.

Essa referência ao conteúdo, significado, ser ou a coisa mesma do texto que a concepção prévia da perfeição empresta ao círculo hermenêutico é, na visão de Gadamer, a condição primária e fundamental da hermenêutica. Em oposição às hermenêuticas da suspeita de Marx, Nietzsche, Freud, Gadamer defende que a hermenêutica se baseia na confiança: “compreender significa primeiramente entender-se na coisa e, só em segundo lugar, apartar e compreender a opinião do outro como tal". Com isso, Gadamer reabilita a hermenêutica no século XX, desacreditada e preterida pela semiótica.

A relação entre autor-texto-leitor, portanto, a partir do círculo hermenêutico, pode ser compreendida sob os dois níveis da linguagem de que fala Heidegger: I) no nível ontológicohermenêutico, o círculo hermenêutico e sua noção de concepção prévia da perfeição retiram a hermenêutica do exílio imposto pela epistemologia positivista no século $X I X^{68}$ e, no século $X X$, pelo estruturalismo e o criticismo, alçando-a a nível universal e filosófico; II) no nível metodológico-apofântico, o círculo hermenêutico serve como caminho analítico-interpretativo, conforme exemplificado por Henriete Karam ${ }^{69}$. Ela demonstra como é possível, pela noção de círculo hermenêutico, apresentar um percurso analítico-interpretativo que rearticule os elementos autor, texto, leitor nos estudos em direito e literatura. Utilizando do conto Suje-se gordo!, de Machado de Assis, como exemplo, Karam dividiu seu percurso analítico-interpretativo em três fases, pressupondo, de saída, "o fato de que a obra literária, por ser uma representação, comporta tanto o mundo representado quanto a sua função de representar"70. Assim,

${ }^{65}$ Id., ibid., 2002, p. 77.

66 Id., ibid., p. 78.

67 Id., ibid., p. 78.

68 Para mais a respeito da "cegueira" positivista, vide KARAM, Henriete. A "poética da visão" de J. Saramago: algumas questões para pensar a hermenêutica jurídica. Anamorphosis - Revista Internacional de Direito e Literatura, v. 4, n. 2, p. 519-524, jul.-dez. 2018.

${ }^{69}$ KARAM, 2017b.

${ }^{70}$ Id., ibid., p. 841. 
ISSN 1981-3694

(DOI): 10.5902/1981369440148

0 mundo representado compreende os eventos narrados e o contexto em que eles se inserem; já a função de representar apresenta duplo vetor, pois, de um lado, tem pontos de ancoragem no contexto histórico de sua produção, ao qual se vincula, e, de outro, é suscetível à atualização, tanto do ponto de vista da produção quanto da recepção ${ }^{71}$.

A primeira etapa do percurso consiste em levantar e analisar os elementos do mundo representado pela narrativa. 0 jurista, devido ao seu próprio horizonte ${ }^{72}$, ao elaborar seu pequeno resumo dos eventos e elementos da narrativa já antecipará as questões políticojurídicas presentes na obra literária. Assume-se o que Gadamer chama de entender-se primeiro com a coisa.

O percurso, em sua segunda fase, determina a investigação do contexto histórico da produção do texto. O papel do autor, nessa etapa, merece ênfase. Trata-se de avaliar qual agenda política o autor apresenta no texto literário e como o contexto da obra reflete isso. Por último, o percurso se completa, circularmente, com a relação entre os eventos narrados no texto literário e o contexto atual do leitor/intérprete ${ }^{73}$. 0 texto literário só pode ser compreendido porque compartilha de uma tradição conosco e, nesse sentido, é possível rearticulá-lo com o presente. Autor, texto, e leitor se (re)articulam, assim, no círculo hermenêutico, possibilitando estudos e pesquisas em direito e literatura que convertam dóxa em epísteme.

\section{O QUE OS ESTUDOS E PESQUISAS EM DIREITO E LITERATURA TÊM A GANHAR COM O DEBATE - O EXEMPLO DE GEORGE ORWELL}

Partiu-se da premissa de que, apesar dos inúmeros benefícios e da evidente expansão do estudo e pesquisa interdisciplinar em Direito e Literatura, a produção bibliográfica nesta área apresenta sério déficit teórico. A maioria dos estudos e pesquisas nessa área - sobretudo aqueles de estudantes de graduação e pós-graduação - se utilizam da literatura de forma instrumental: o texto literário serve como um adorno que enverniza a (hipó)tese do pesquisador. Em termos hermenêuticos, como abordado acima, simplesmente se deduz do texto o que já se atribuiu a ele, de antemão.

\footnotetext{
71 Id., ibid., p. 841.

72 "O conceito de horizonte possibilita contemplar a implicação das disposições individuais do leitor - os conteúdos da consciência, as intuições temporalmente condicionadas e a história de suas experiências - na estruturação e na significação que emergem no processo de leitura, processo que pressupõe compreensão e, portanto, interpretação e no qual se situaria, acrescente-se, a origem de todo e qualquer ato de nova produção escritural" (KARAM, 2017b, p. 1029).

73 KARAM, 2017b.
} 
ISSN 1981-3694

(DOI): $10.5902 / 1981369440148$

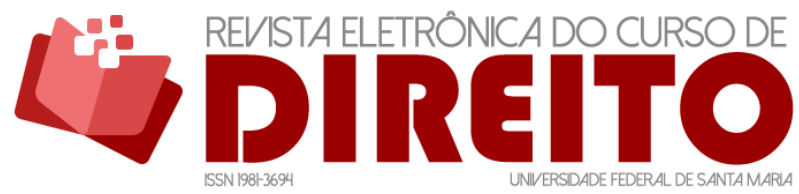

O PAPEL DO AUTOR NOS ESTUDOS DO DIREITO NA OU ATRAVÉS

DA LITERATURA

ANDRÉ KARAM TRINDADE HENRIETE KARAM

GUILHERME GONÇALVES ALCÂNTARA

Considerando que a função do autor é um dos temas mais relevantespara a teoria literária moderna, o pesquisador em direito e literatura precisa tomar consciência dos contornos dessa questão, bem como se posicionar teoricamente diante dela.

Viu-se, acima, como a noção de círculo hermenêutico atua tanto no nível ontológicohermenêutico quanto no nível metodológico-apofântico, suspendendo a consciência hermenêutica dos seus pré-juízos e articulando a relação autor-texto-leitor de forma analítica. Oferece-se, assim, um caminho analítico-interpretativo apto a articular autor, texto e leitor.

A relação da literatura com o direito é, com efeito, funcional e talvez até pragmática, mas não no sentido ornamental ou decorativo que denunciaram Trindade e Bernsts. Essa relação funcional é apresentada por lan Ward com dois sentidos. Em primeiro lugar, Ward defende uma função pedagógica dos textos literários, dado seu potencial humanizador. Em segundo lugar, certos textos literários apresentam agendas políticas, cuja compreensão pode abrir possibilidades para uma sociedade menos cruel. Rorty partilha dessa opinião, exemplificando com as obras de George Orwell e Nobokov.

É sobre esse segundo aspecto que a relação autor-texto-leitor ganha maior relevância. É muito fácil para a propaganda liberal denunciar os males do regime soviético a partir de $A$ revolução dos bichos $^{74}$ e de $1984^{75}$, de forma a defender e promover a liberdade liberalindividualista burguesa. Tal conclusão é intelectualmente acanhada, não sai da dóxa, do senso comum teórico. A partir de que se toma consciência de que Orwell (Arthur Blair) lutou ao lado dos comunistas na Espanha, de sua aberta inclinação aos ideais da esquerda, ou seja, a partir da compreensão do contexto histórico do autor, fica muito mais difícil defender essa interpretação de suas obras. Sua agenda política não coincide, como parece, com a agenda liberal. Trata-se de uma luta pela democracia, ameaçada tanto pelo socialismo quanto pelo liberalismo, em sua época.

Orwell finalizou 1984 em 1948, o que explica o título. A obra foi lançada no ano seguinte, no despontar da disputa ideológica, econômica e política que caracterizou a Guerra Fria até a queda da União Soviética. A primeira metade do século XX foi marcada pelo abandono dos princípios políticos e econômicos liberais clássicos e pelo surgimento de regimes totalitários. Assim, o fato de o partido, na narrativa, receber o nome Ingsoc (remetendo ao socialismo) reflete a tendência da época - a própria Inglaterra de Orwell era governada pelo partido socialista. Os rumos da história, contudo, foram outros. No plano ideológico, o capitalismo

${ }^{74}$ ORWELL, George. A revolução dos bichos. Trad. Heitor Aquino Ferreira. São Paulo: Globo, 2002.

75 ORWELL, George. 1984. Trad. de Alexandre Hubner e Heloisa Jahn. São Paulo, Comp. das Letras, 2009. 
ISSN 1981-3694

(DOI): 10.5902/1981369440148

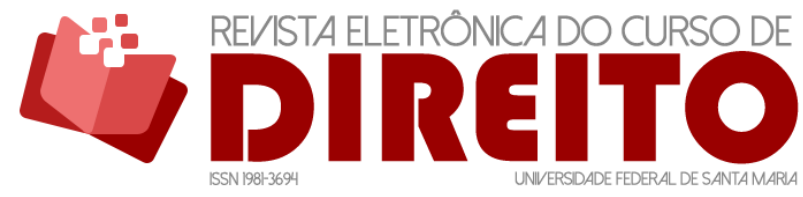

O PAPEL DO AUTOR NOS ESTUDOS DO DIREITO NA OU ATRAVÉS

DA LITERATURA

ANDRÉ KARAM TRINDADE HENRIETE KARAM

GUILHERME GONÇALVES ALCÂNTARA

prevaleceu sobre o socialismo, na política econômica, o discurso social keynesiano cedeu espaço ao neoliberalismo ${ }^{76}$ do Consenso de Washington ${ }^{77}$. É preciso, pois, “privilegiar tanto o contexto histórico-cultural, que abarca a inscrição e circulação dos signos e se concretiza no eixo da intersubjetividade [...], quanto as experiências vividas por cada sujeito no espaço-tempo da sua própria subjetividade, ou seja, em sua facticidade e historicidade"78.

Orwell continua vivo, mesmo com a declaração do fim da história de Fukuyama. A perda do poder político dos Estados para os conglomerados corporativos transnacionais, que formam continentes; o uso do direito penal como arma de governo; a pretensão meta-linguística - aos moldes da novilíngua - da escola austríaca de economia; o emprego de novas tecnologias na segurança pública e privada, que colocam em xeque a liberdade individual em nome da segurança ${ }^{79}$; as inúmeras intervenções militares dos Estados Unidos, da segunda metade do

\footnotetext{
${ }^{76}$ Mcchesney define neoliberalismo como "o paradigma econômico e político que define o nosso tempo. Ele consiste em um conjunto de políticas e processos que permitem a um número relativamente pequeno de interesses particulares controlar a maior parte possível da vida social com o objetivo de maximizar seus benefícios individuais. Inicialmente associado a Reagan e Thatcher, o neoliberalismo é a principal tendência da política e da economia globais nas últimas duas décadas, seguida, além da direita, por partidos políticos de centro e por boa parte da esquerda tradicional. Esses partidos e suas políticas representam os interesses imediatos de investidores extremamente ricos e de menos de mil grandes empresas. [...] No final, os neoliberais não têm como apresentar, como não apresentam de fato, a defesa empírica do mundo que estão construindo. Ao contrário, eles apresentam - ou melhor, exigem uma fé religiosa na infalibilidade do mercado desregulado, que remonta a teorias do século 19 que pouco têm a ver com o nosso mundo. 0 grande trunfo dos defensores do neoliberalismo, no entanto, é a alegada inexistência de alternativas." (MCCHESNEY, Robert W. Introdução. In CHOMSKY, Noam. O lucro ou as pessoas. Trad. de Pedro Jorgensen Jr. São Paulo: Bertrand Brasil, 2002. p. 3).

77 Segundo Chomsky, "O Consenso [neoliberal] de Washington é um conjunto de princípios orientados para o mercado, traçados pelo governo dos Estados Unidos e pelas instituições financeiras internacionais que ele controla e por eles mesmos implementados de formas diversas - geralmente, nas sociedades mais vulneráveis, como rígidos programas de ajuste estrutural. Resumidamente, as suas regras básicas são: liberalização do mercado e do sistema financeiro, fixação dos preços pelo mercado ("ajuste de preços"), fim da inflação ("estabilidade macroeconômica") e privatização. Os governos devem "ficar fora do caminho" - portanto, também a população, se o governo for democrático -, embora essa conclusão permaneça implícita" (CHOMSKY, Noam. O lucro ou as pessoas. Trad. de Pedro Jorgensen Jr. São Paulo: Bertrand Brasil, 2002. p. 9).

${ }^{78}$ KARAM, 2017a, p. 1029.

${ }^{79}$ Convém destacar o que assinalam Bauman e May, "Os medos não têm raiz. Essa característica líquida do medo faz com que ele seja explorado política e comercialmente. Os políticos e os vendedores de bens de consumo acabam transformando esse aspecto em um mercado lucrativo. [...] Adquirir bens para obter segurança só alivia uma parte da tensão e mesmo assim, por um breve tempo. Para os governos e o mercado, é interessante manter acesos esses medos e, se possível, até estimular o aumento da insegurança. Como a fonte das ansiedades parece distante e indefinida, é como se dependêssemos dos especialistas, das pessoas que entendem do assunto, para mostrar onde estão as causas do sofrimento e como lutar contra ele. Não temos como testar a verdade que nos contam. Só nos resta então acreditar no que dizem" (BAUMAN, Zygmunt; MAY, Tim. Capitalismo parasitário: e outros temas contemporâneos. Trad. de Eliana Aguiar. Rio de Janeiro: J. Zahar, 2010. p. 74-75).
} 
ISSN 1981-3694

(DOI): 10.5902/1981369440148

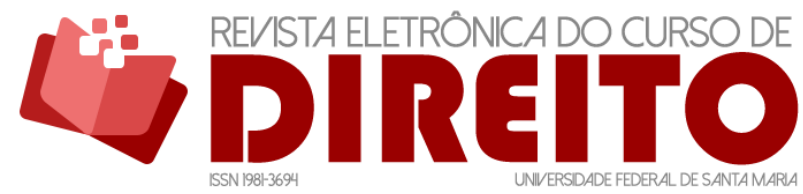

O PAPEL DO AUTOR NOS ESTUDOS DO DIREITO NA OU ATRAVÉS

DA LITERATURA

ANDRÉ KARAM TRINDADE HENRIETE KARAM

GUILHERME GONÇALVES ALCÂNTARA

século XX até nossos dias; a espetacularização da cultura e da política ${ }^{80}$; o tecnicismo no lugar da democracia ${ }^{81}$; o revisionismo histórico ordoliberal - todas essas vivências presentes determinam, outrossim, a interpretação dos lemas guerra é paz, ignorância é força, liberdade é escravidão, presentes em 1984, pois eles também valiam para o projeto utópico das democracias-liberais do pós-guerra, hoje desmontado pelos próprios liberais:

A globalização econômica é tão-somente a realizadora, nesta perspectiva sombria, daquilo que a pós-modernidade pôs em curso, em termos intelectuais, e a individualização, em termos políticos: a dissolução da modernidade. Eis o diagnóstico: o capitalismo gera desemprego e não dependerá do trabalho. E assim cai por terra a história aliança entre economia de mercado, Estado do bem-estar social e democracia que legitimou e integrou, até o presente momento, o modelo ocidental e o projeto do Estado nacional para a modernidade. Por este ângulo, os neoliberais transformam-se nos desmontadores do Ocidente - mesmo quando surgem como reformadores. Eles alavancam, no que diz respeito ao Estado do bem-estar social, à democracia e à esfera pública, uma modernização que os conduz à morte ${ }^{82}$.

Atualmente, “o inimigo já não é a conspiração revolucionária dos pretensos administradores do estado", como destaca Bauman ${ }^{83}$. A reprodução da ordem social, no despontar do século XXI, fica a cargo das forças invisíveis e desregulamentadas do mercado, sob os ideais de liberdade que o liberalismo econômico tanto prega. Nem por isso, a sensação de insegurança universalmente compartilhada diminuiu. 0 que se percebe é que "a estrada dos cortes do bem-estar pode levar a toda parte, menos a uma sociedade de indivíduos livres" ${ }^{84}$. Em carta escrita quatro anos antes da produção de 1984, Orwell explica a um leitor porque a tendência totalitarista estava de fato crescendo na Inglaterra e nos Estados Unidos, ao invés de diminuindo, como aparentava:

80 “É assim que se faz a História nestes anos finais do século XX. A televisão não se limita a chegar primeiro, também quer ser encenadora de um espetáculo" (GIDDENS, Anthony. 0 mundo na era da globalização. Trad. de Saul Barata. 6. ed. Lisboa: Presença. 2006. p. 69).

81 "O atual leque de políticas públicas em discussão tem tão pouca relevância programática quanto seus numerosos antecedentes: nem os Estados Unidos nem qualquer outro poder orientaram-se pelo "meliorismo global". A democracia está sendo atacada no mundo inteiro, até mesmo nos principais países industrializados; pelo menos a democracia no sentido significativo da palavra, que supõe oportunidades para as pessoas tratarem de seus próprios assuntos coletivos e individuais. [...] A América Latina é a área de testes óbvia, especialmente a América Central e o Caribe. Aqui, Washington enfrentou poucos desafios externos durante quase um século, de modo que os princípios norteadores da sua política, assim como do atual 'Consenso [neoliberal] de Washington', se revelam de um modo claríssimo quando examinamos a situação da região e como se chegou a ela" (CHOMSKY, op. cit., p. 48-49).

82 BECK, Ulrich. 0 que é globalização?: equívocos do globalismo; respostas à globalização. Trad. de André Carone. São Paulo: Paz e Terra, 1999. p. 25-26.

83 BAUMAN, Zygmunt. 0 mal-estar da pós-modernidade. Trad. de Mauro Gama e Cláudia Martinelli Gama. Rio de Janeiro: J. Zahar, 1998. p. 53.

${ }^{84}$ Id., ibid., p. 252. 
ISSN 1981-3694

(DOI): 10.5902/1981369440148

Sem dúvida, Hitler desaparecerá em breve, mas apenas às custas de fortalecer (a) Stalin, (b) os milionários anglo-americanos e (c) todos os tipos de pequenos fuhrers - do tipo de de Gaulle. Todos os movimentos nacionais em todos os lugares, mesmo aqueles que se originam da resistência à dominação alemã, parecem tomar formas não democráticas, agrupar-se em torno de algum fuhrer sobre-humano (Hitler, Stalin, Salazar, Franco, Gandhi, De Valera são todos exemplos variados) e adotar a teoria de que o fim justifica os meios. Em toda parte, o movimento mundial parece estar na direção de economias centralizadas que podem ser feitas para "funcionar" em um sentido econômico, mas que não são democraticamente organizadas e tendem a estabelecer um sistema de castas. [...] Para começar, há a indiferença geral à decadência da democracia. Você percebe, por exemplo, que ninguém na Inglaterra com menos de 26 anos agora votam e que, até onde se pode ver, a grande massa de pessoas daquela idade não dá a mínima para isso? Em segundo lugar, há o fato de que os intelectuais possuem perspectivas mais totalitárias do que as pessoas comuns. Em geral, a intelligentsia inglesa opôs-se a Hitler, mas apenas ao preço de aceitar Stalin. A maioria deles está perfeitamente preparada para métodos ditatoriais, polícia secreta, falsificação sistemática de história, etc., desde que eles sintam que estão do lado "nosso". De fato, a afirmação de que não temos um movimento fascista na Inglaterra significa, em grande parte, que os jovens, neste momento, procuram seu fuhrer em outro lugar. [...] Você também pergunta, se eu acho que a tendência mundial é para o fascismo, por que eu apoio a guerra? É uma escolha de males - imagino que quase toda guerra é essa. Eu conheço o suficiente do imperialismo britânico para não gostar dele, mas eu o apoiaria contra o nazismo ou o imperialismo japonês, como o mal menor. Similarmente, eu apoiaria a URSS contra a Alemanha porque acho que a URSS não pode escapar completamente do seu passado e retém o suficiente das idéias originais da Revolução para torná-lo um fenômeno mais esperançoso do que a Alemanha nazista. Eu penso, e tenho pensado desde que a guerra começou, em 1936 ou por aí, que a nossa causa é a melhor, mas temos que continuar a melhorar, o que envolve críticas constantes ${ }^{85}$.

Essa carta revela que a preocupação maior de Orwell não era com a questão soviética, mas, antes, com a derrocada da democracia. Setenta anos após 1984, em um mundo onde o mercado reina absoluto e prega a extinção do Estado, em que o bem público se privatiza tornando a expressão República vazia -, o que está em jogo, diz Pierre Bourdieu, "é a reconquista da democracia contra a tecnocracia [...] acabar com a tirania dos especialistas, estilo Banco Mundial ou FMI [...] que não querem negociar, mas explicar"86. Richard Rorty disse em 1989 - que, quarenta anos após Orwell, ainda não encontramos maneira melhor de descrever

85 Disponível em: https://www.thedailybeast.com/george-orwells-letter-on-why-he-wrote-1984. Acesso em: 20 set. 2019.

86 BOURDIEU, Pierre. Contrafogos: táticas para enfrentar a invasão neo-liberal. Tradução de Lucy Magalhães. Rio de Janeiro: J. Zahar, 1998. p. 25. 
ISSN 1981-3694

(DOI): $10.5902 / 1981369440148$

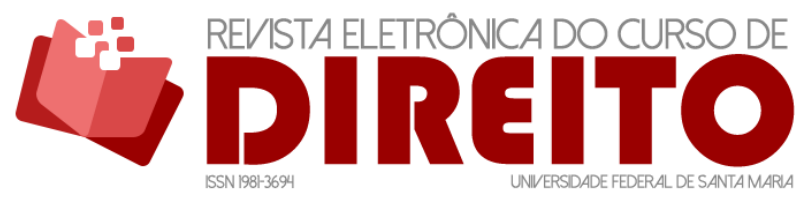

O PAPEL DO AUTOR NOS ESTUDOS DO DIREITO NA OU ATRAVÉS

DA LITERATURA

ANDRÉ KARAM TRINDADE HENRIETE KARAM

GUILHERME GONÇALVES ALCÂNTARA

nosso impasse político, que balança entre o liberalismo, conservador e ganancioso, e a oligarquia comunista $^{87}$. Tal afirmativa continua válida.

É importante destacar que apenas compreendemos 1984 porque - e na medida em que estamos distanciados dele. Uma interpretação, aos moldes da propaganda (neo)liberal, que se mantém na tese de que o regime soviético seria o (único) alvo de Orwell é uma interpretação fraca, para não dizer estéril. Não abre possibilidades, resta sempre o velho liberalismo e seu culto ao mercado. Evidencia-se, assim, o quanto o conhecimento a respeito do contexto histórico do autor ${ }^{88}$ é fundamental para a interpretação da obra literária.

\section{CONCLUSÃO}

A hermenêutica - seja a literária, seja a jurídica, seja a histórica - não aceita relativismos. Não se pode dizer qualquer coisa sobre a obra literária, utilizando-a de forma decorativa. Todo intérprete possui um horizonte de sentido, conformado pela tradição históricolinguística, balizadora de sua compreensão sobre os textos. A experiência hermenêutica, quando bem sucedida, acarreta sempre mudança no horizonte do intérprete, caso contrário, permaneceríamos somente reproduzindo o senso comum. Muitas das pesquisas em direito e literatura padecem deste problema: o texto literário não revolve o chão linguístico em que se encontram os juristas, na medida em que sua função é meramente apelativa, retórica, instrumental. Não se produz epísteme, somente se reproduz a dóxa.

É preciso levar a literatura a sério. Isso não equivale a ignorar seu potencial funcional para as pesquisas jurídicas. Se, de um lado, a literatura é um instrumento; por outro, não deixa de exigir sabedoria e método de uso. O conhecimento dos problemas centrais da teoria literária, assim, é indispensável para que a prática interdisciplinar entre Direito e Literatura produza algum benefício para a comunidade jurídica, e este ensaio procurou trazer à tona o problema do papel do autor.

Enquanto a teoria literária, nos idos do século XIX, girava toda em torno da intenção do autor por detrás do texto; hoje, é lugar comum proclamar sua morte. Apegamo-nos, nas primeiras seis décadas do século $X X$, ao texto, sob a influência do formalismo, do estruturalismo e do new critiicism, e, mais recentemente, ao leitor, sob o signo dos postulados da Estética da

\footnotetext{
${ }^{87}$ RORTY, Richard. Contingency, irony, and solidarity. Cambridge Universitiy Press. 1995. p. 170.

${ }^{88}$ Não se confunda contexto histórico do autor com informações sobre a vida íntima ou funcionamento psíquico do autor.
} 
ISSN 1981-3694

(DOI): $10.5902 / 1981369440148$

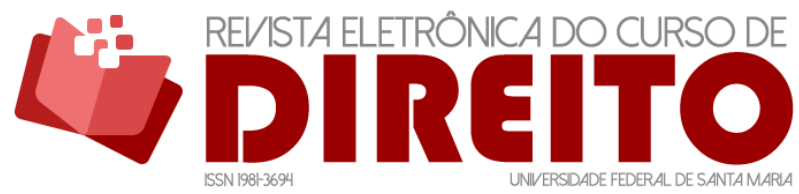

O PAPEL DO AUTOR NOS ESTUDOS DO DIREITO NA OU ATRAVÉS

DA LITERATURA

ANDRÉ KARAM TRINDADE HENRIETE KARAM

GUILHERME GONÇALVES ALCÂNTARA

recepção. Um dos objetivos deste artigo foi, entretanto, borrar essa evolução histórica, na medida em que existem importantes vozes que criticam a tese da morte do autor, como Bloom e Hirsch. O papel do autor na interpretação da obra literária ainda suscita muito debate acadêmico e talvez nunca seja resolvido definitivamente no âmbito da teoria literária.

Dada essa aporia, a proposta foi apresentar a noção de círculo hermenêutico - oriunda da retórica antiga, trazida à modernidade por Scheleiermacher e reinterpretada por Heidegger e Gadamer -, com o propósito de demonstrar a necessidade e a possibilidade de articulação entre autor, texto e leitor - com propõe Henriete Karam -, na interpretação do texto literário.

Assim, a interpretação de questões políticas e jurídicas em obras literárias, atividade típica do campo de estudos do Direito na ou através da Literatura: I) já está sempre inserida em pré-concepções de mundo que o intérprete possui, como condição de possibilidade da compreensão e; II) necessita de um percurso analítico-interpretativo que permita o revolvimento desses pré-juízos e conduza a produzir algum ganho de conhecimento.

Para demonstrar a relevância que o contexto histórico do autor adquire na atribuição de sentido, recorreu-se a 1984, de George Orwell, que não é - somente - um libelo contra a URSS, como faz parecer a propaganda (neo)liberal. Saber que Arthur Blair lutou ao lado dos comunistas na Espanha e que seu maior medo era o déficit democrático dos governos liberais não permite chegar à conclusão dos "neoliberais".

Por outro lado, se 1984 ainda nos fala - talvez mais do que quando da sua publicação - é porque compartilhamos algumas de suas experiências. Os rumos da história demonstraram, pois, que a vitória do capitalismo sobre o socialismo produz a mesma supressão da liberdade que a exercida pelo Ingsoc de Orwell. Um estudo em direito e literatura sobre 1984, caso siga o percurso analítico-interpretativo apresentado por Karam, articularia o horizonte de sentido captado pelo estudo do contexto histórico do autor do texto, com o horizonte de sentido do leitor, situado no presente, tendo por baliza o mundo representado na obra literária. "Finda a história", vitoriosas as democracias liberais, porque Orwell ainda nos fala tão alto? Essa pergunta promoveria novas leituras de 1984.

\section{REFERÊNCIAS}

BAKHTIN, Mikhail. Questões de literatura e de estética: a teoria do romance. Trad. de Aurora Fornoni Bernardini et al. São Paulo: Unesp; Hucitec, 1988. 
ISSN 1981-3694

(DOI): $10.5902 / 1981369440148$

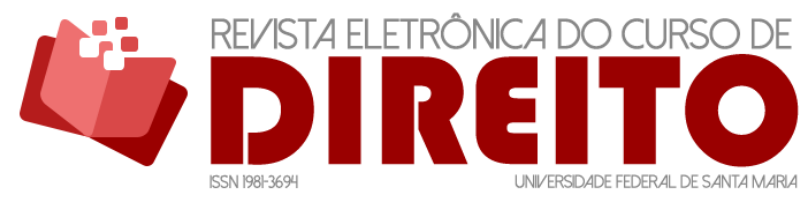

O PAPEL DO AUTOR NOS ESTUDOS DO DIREITO NA OU ATRAVÉS

DA LITERATURA

ANDRÉ KARAM TRINDADE HENRIETE KARAM

GUILHERME GONÇALVES ALCÂNTARA

BARTHES, Roland. A morte do autor. In: BARTHES, Roland. 0 rumor da língua. Trad. de Mario Laranjeira. 2. ed. São Paulo: Martins Fontes, 2004. p. 57-64.

BARTHES, Roland. 0 prazer do texto. Trad. de J. Guinsburg. 3. ed. São Paulo: Perspectiva, 2002.

BAUMAN, Zygmunt; MAY, Tim. Capitalismo parasitário: e outros temas contemporâneos. Trad. de Eliana Aguiar. Rio de Janeiro: J. Zahar, 2010.

BAUMAN, Zygmunt. 0 mal-estar da pós-modernidade. Trad. de Mauro Gama e Cláudia Martinelli Gama. Rio de Janeiro: J. Zahar, 1998.

BECK, Ulrich. 0 que é globalização?: equívocos do globalismo; respostas à globalização. Trad. de André Carone. São Paulo: Paz e Terra, 1999.

BENJAMIN, Walter. Obras escolhidas, I; Magia e técnica, arte e política: ensaios sobre literatura e história da cultura. Trad. de Sérgio Paulo Rouanet. 3. ed, São Paulo: Brasiliense. 1987.

BLOOM, Harold. O cânone ocidental. Rio de Janeiro: Objetiva, 2010.

BOURDIEU, Pierre. Contrafogos: táticas para enfrentar a invasão neo-liberal. Tradução de Lucy Magalhães. Rio de Janeiro: J. Zahar, 1998.

CANDIDO, Antonio. Vários escritos. 5. ed. Rio de Janeiro: Ouro sobre Azul, 2013.

CHOMSKY, Noam. O lucro ou as pessoas. Trad. de Pedro Jorgensen Jr. São Paulo: Bertrand Brasil, 2002.

COMPAGNON, Antoine. 0 demônio da teoria: literatura e senso comum. Trad. de Cleonice Paes Barreto Mourão. Belo Horizonte: Ed. UFMG, 1999.

DWORKIN, Ronald. 0 império do direito. Trad. de Jefferson Luiz Camargo. São Paulo: Martins Fontes, 2003.

EAGLETON, Terry. Teoria da literatura: uma introdução. Trad. de Waltemir Dutra. 6. ed. São Paulo: Martins Fontes, 2006.

ESPÍNDOLA, Angela Araújo da Silveira. Entre a insustentabilidade e a futilidade: a jurisdição, o direito e o imaginário social sobre o juiz. Anamorphosis - Revista Internacional de Direito e Literatura, v. 2, n. 2, p. 293-320, jul.-dez. 2016. Doi:

http://dx.doi.org/10.21119/anamps.22.293-320.

FOUCAULT, Michel. O que é um autor? Lisboa: Veja, 2002.

GAAKEER, Jeanne. Por que o direito precisa das ciências humanas: julgando pela experiência. Anamorphosis - Revista Internacional de Direito e Literatura, v. 5, n. 1, p. 5-14, jan.-jun. 2019. Doi: http://dx.doi.org/10.21119/anamps.51.5-14.

GADAMER, Hans-Georg. Estética y Hermenéutica. Trad. de José Francisco Zúñiga García. Daimon - Revista Internacional de Filosofía, n. 12, p. 1-8, 1996. 
ISSN 1981-3694

(DOI): $10.5902 / 1981369440148$

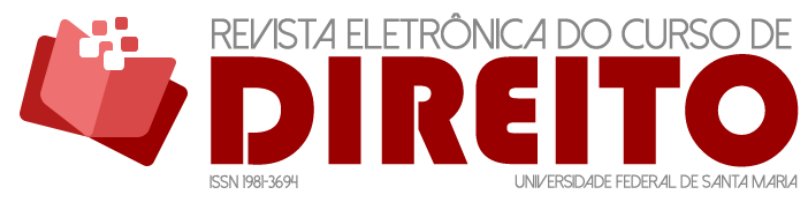

O PAPEL DO AUTOR NOS ESTUDOS DO DIREITO NA OU ATRAVÉS

DA LITERATURA

ANDRÉ KARAM TRINDADE HENRIETE KARAM

GUILHERME GONÇALVES ALCÂNTARA

GADAMER, Hans-Georg. Verdade e método, vol. I: traços fundamentais de uma hermenêutica filosófica. Trad. de Flávio Paulo Meurer. Petrópolis: Vozes, 1997.

GADAMER, Hans-Georg. Verdade e método, vol. II: complementos e índices. Trad. de Ênio Paulo Giachini. Petrópolis: Vozes. 2002.

GENETTE, G. Fronteiras da narrativa. In: BARTHES, R. et al. Análise estrutural da narrativa. Trad. de Maria Zélia Barbosa Pinto. Petrópolis: Vozes, 2011. p. 255-274.

GIDDENS, Anthony. 0 mundo na era da globalização. Trad. de Saul Barata. 6. ed. Lisboa: Presença. 2006.

GRONDIN, Jean. Introdução à hermenêutica filosófica. Trad. de Benno Dischinger. São Leopoldo: Ed. UNISINOS, 1999.

HIRSCH JR., E. D. Validity in interpretation. Chelsea, Michigan: BookCrafters, Inc. 1967.

ISER, Wolfgang. O jogo do texto. In: LIMA, Luiz Costa (org.). A literatura e o leitor: textos de estética da recepção. São Paulo: Paz e Terra, 2002. p. 105-118.

JALES, Túlio de Medeiros. Quem é o leitor de textos jurídicos? Uma exploração sobre os ombros de Ricardo Piglia. Anamorphosis - Revista Internacional de Direito e Literatura, v. 3, n. 1, p. 2537, jan.-jun. 2017. Doi: http://dx.doi.org/10.21119/anamps.31.25-37.

KARAM, Henriete. A “poética da visão" de J. Saramago: algumas questões para pensar a hermenêutica jurídica. Anamorphosis - Revista Internacional de Direito e Literatura, v. 4, n. 2, p. 519-524, jul.-dez. 2018. Doi:http://dx.doi.org/10.21119/anamps.42.519-524.

KARAM, Henriete. 0 direito na contramão da literatura: a criação no paradigma contemporâneo. Revista Eletrônica do Curso de Direito da UFSM, v. 12, n. 3, p. 1022-1043, dez. 2017a. Doi: http://dx.doi.org/10.5902/1981369429566.

KARAM, Henriete. Questões teóricas e metodológicas do direito na literatura: um percurso analítico-interpretativo a partir do conto "Suje-se gordo!", de Machado de Assis. Rev. direito GV, v. 13, n. 3, p. 827-865, dez. 2017b. Doi: http://dx.doi.org/10.1590/2317-6172201733.

KORFMANN, Michael. A diferenciação da literatura moderna alemã no processo constitutivo da sociedade funcional: uma abordagem sistêmica baseada em Niklas Luhman. 2002. 274 f. Tese (Doutorado em Letras)- Instituto de Letras, Universidade Federal do Rio Grande do Sul, Porto Alegre, 2008.

MCCHESNEY, Robert W. Introdução. In CHOMSKY, Noam. O lucro ou as pessoas. Trad. de Pedro Jorgensen Jr. São Paulo: Bertrand Brasil, 2002. p. 7-17.

ORWELL, George. A revolução dos bichos. Trad. Heitor Aquino Ferreira. São Paulo: Globo, 2002. ORWELL, George. 1984. Trad. de Alexandre Hubner e Heloisa Jahn. São Paulo, Comp. das Letras, 2009. 
ISSN 1981-3694

(DOI): 10.5902/1981369440148

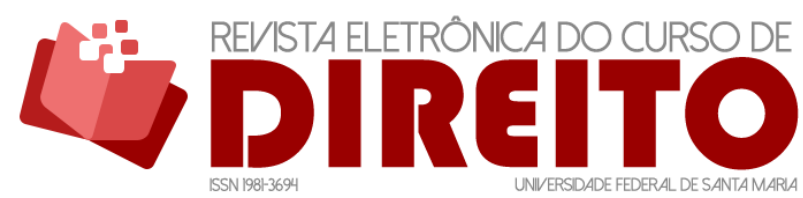

O PAPEL DO AUTOR NOS ESTUDOS DO DIREITO NA OU ATRAVÉS

DA LITERATURA

ANDRÉ KARAM TRINDADE HENRIETE KARAM

GUILHERME GONÇALVES ALCÂNTARA

OST, François. Direito e literatura: os dois lados do espelho. Anamorphosis - Revista

Internacional de Direito e Literatura, v. 3, n. 1, p. 259-274, jan.-jun. 2017. doi:

http://dx.doi.org/10.21119/anamps.31.259-274.

PÊPE, Albano Marcos Bastos. Direito e literatura: uma intersecção possível? Interlocuções com o pensamento waratiano. Anamorphosis - Revista Internacional de Direito e Literatura, v. 2, n. 1, p. 5-15, jan.-jun. 2016. Doi: http://dx.doi.org/10.21119/anamps.21.5-15.

RORTY, Richard. Contingency, irony, and solidarity. Cambridge Universitiy Press. 1995.

SCHELEIERMACHER, Friedrich D. Hermenêutica e crítica: com anexos de Scheleiermacher sobre filosofia da linguagem, vol. I. Trad. de Aloísio Ruedell. Ijuí: Ed. Ijuí, 2005.

SEATON, James. Law and Literature: Works, Criticism, and Theory. Yale Journal of Law \& the Humanities, v. 11, iss. 2, Article 8, p. 479-507, 1999. Disponível em:

http://digitalcommons.law.yale.edu/yjlh/vol11/iss2/8. Acesso em: 20 set. 2019.

STRECK, Lenio Luiz; KARAM, Henriete. A literatura ajuda a existencializar o direito.

Anamorphosis - Revista Internacional de Direito e Literatura, v. 4, n. 2, p. 615-626, jul. -dez.

2018. Doi: http://dx.doi.org/10.21119/anamps.42.615-626.

TODOROV, Tzvetan. As estruturas narrativas. Trad. de Leyla Perrone-Moisés. São Paulo:

Perspectiva, 2006.

TRINDADE, André Karam. Direito, literatura, emancipação: um ensaio sobre o poder das narrativas. Revista Jurídica, v. 3, n. 44, p. 86-116, 2016.

TRINDADE, André Karam; BERNSTS, Luísa Giuliani. O estudo do Direito e literatura no Brasil: surgimento, evolução e expansão. Anamorphosis - Revista Internacional de Direito e Literatura, Porto Alegre, RDL, v. 3, n. 1, p. 225-257, jan.-jun. 2017. Doi:

http://dx.doi.org/10.21119/anamps.31.225-257.

WEISBERG, Robert. The Law-Literature Enterprise. Yale Journal of Law \& the Humanities, v. 1, iss. 1, Article 4, p. 1-68, 1989. Disponível em:

http://digitalcommons.law.yale.edu/yjlh/vol1/iss1/4. Acesso em: 20 set. 2019.

WEST, Robin. Economic Man and Literary Woman: One Contrast. Georgetown Public Law and Legal Theory Research, Paper n. 11-52. Georgetown University Law Center, 1988.

ZIZEK, Slavoj. A visão em paralaxe. Trad. de Maria Beatriz de Medina. São Paulo: Boitempo, 2008. 
ISSN 1981-3694

(DOI): $10.5902 / 1981369440148$

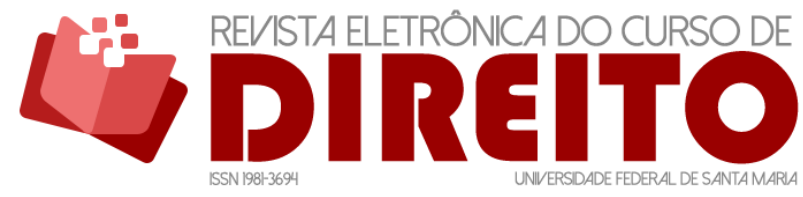

O PAPEL DO AUTOR NOS ESTUDOS DO DIREITO NA OU ATRAVÉS

DA LITERATURA

ANDRÉ KARAM TRINDADE HENRIETE KARAM

GUILHERME GONÇALVES ALCÂNTARA

\section{COMO FAZER REFERÊNCIA AO ARTIGO (ABNT):}

TRINDADE, André Karam; KARAM, Henriete; ALCÂNTARA, Guilherme Gonçalves. 0 papel do autor nos estudos do direito na ou através da literatura. Revista Eletrônica do Curso de Direito da UFSM, Santa Maria, RS, v. 14, n. 3, e40148, set./dez. 2019. ISSN 1981-3694. DOI: http://dx.doi.org/10.5902/1981369440148. Disponível em:

https://periodicos.ufsm.br/revistadireito/article/view/40148 Acesso em: dia mês. ano.

Direitos autorais 2019 Revista Eletrônica do Curso de Direito da UFSM

Editores responsáveis: Rafael Santos de Oliveira e Angela Araujo da Silveira Espindola

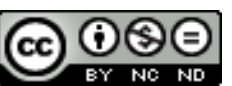

Esta obra está licenciada com uma Licença Creative Commons Atribuição-NãoComercial-SemDerivações 4.0 Internacional.

\section{SOBRE OS AUTORES}

\section{ANDRÉ KARAM TRINDADE}

Possui Graduação em Direito (ULBRA), Mestrado em Direito Público (UNISINOS) e Doutorado em Teoria e Filosofia do Direito (Università Degli Studi Roma Tre/Itália). Coordenador do Programa de Pós-Graduação Stricto Sensu em Direito da UniFG, onde também coordena o SerTão - Núcleo Baiano de Direito e Literatura (DGP/CNPq). Professor Externo do Programa de Doctorado em Ciencias Jurídicas y Sociales da Universidad de Málaga (Espanha). Foi presidente da Rede Brasileira Direito e Literatura (2014-2018). Editor-Chefe da ANAMORPHOSIS - Revista Internacional de Direito e Literatura. Produtor Executivo do Programa Direito \& Literatura, exibido semanalmente pela TV JUSTICA. Membro do Grupo de Investigación Intertextos entre el Derecho y la Literatura (USFQ/Equador). Tem experiência na área do Direito, com ênfase na Teoria do Direito, Filosofia do Direito e Direito Público, atuando principalmente nos seguintes temas: direito constitucional, hermenêutica jurídica, direito e literatura. Membro do Comitê de Área Interdisciplinar (Câmara de Ciências Sociais e Aplicadas e Humanidades) da CAPES, de 2010 a 2013. Consultor Ad Hoc da Área do Direito da CAPES, FAPERGS e FAPESB. Membro da Comissão de Estudos Constitucionais da OAB/RS. Sócio do Escritório Streck \& Trindade Advogados Associados.

\section{HENRIETE KARAM}

Possui Mestrado em Teoria da Literatura, pela Pontifícia Universidade Católica do Rio Grande do Sul (PUCRS), e Doutorado em Estudos Literários, pela Universidade Federal do Rio Grande do Sul (UFRGS). É professora de Hermenêutica Jurídica no Programa de Pós-Graduação em Direito da Faculdade Guanambi (FG); professora-colaboradora, do Programa de PósGraduacão em Letras da Universidade Federal do Rio Grande do Sul (UFRGS); e professora-convidada da Especialização em Psicanálise da Universidade do Vale do Rio dos Sinos (UNISINOS). Pertence à Rede Brasileira Direito e Literatura (RDL), na condição de Membro-Fundadora e de Editora-Chefe da Anamorphosis - Revista Internacional de Direito e Literatura (Qualis A2), publicação científica da RDL. Faz parte do Quadro Permanente de Professores que participam do Programa Direito \& Literatura (TV Justiça). Dedica-se ao estudo de temas relacionados (1) à contribuição da literatura para a problematização e reflexão de questões pertinentes ao âmbito do direito; (2) à hermenêutica jurídica e argumentação, enfocando ideologia, 'produção e análise discursiva; e (3) à psicanálise, à semiótica e à teoria literária, abordando, principalmente, a construção narrativa do eu, subjetividade e memória, identidade e alteridade, imagens do eu, produção discursiva e imaginário.

\section{GUILHERME GonÇALVES ALCÂNTARA}

Mestre em Fundamentos e Efetividade do Direito pelo programa de pós-graduação stricto sensu do Centro Universitário UniFG. Integrante do grupo de pesquisa 'Ser-Tão - Núcleo Baiano de Direito e Literatura' e do grupo de pesquisa em Ética, autonomia e fundamentos do Direito. Professor de Direito Constitucional, Hermenêutica Jurídica e Direito Processual Civil no Centro Universitário Uni-FG. Ex-Bolsista CAPES-PROSUP. Advogado 